\title{
CHARACTERISTICS OF GREEN PEPPER - TREATED PROBIOTIC DOMIATI CHEESE
}

\author{
K. M. K. Kamaly, Kh. M. K. Kebary, R. M. Badawi and A. M. A. Gaafar \\ Dairy Sci. and Tech. Department, Faculty of Agriculture, Menoufia Univ.
}

Received: Feb. 12, 2018

Accepted: Mar. 5, 2018

\begin{abstract}
Six treatments of Domiati cheese were made to study the effect of adding sweet pepper extract and bifidobacteria on cheese quality. Control and all cheese treatments are pickled and stored in refrigerator for 12 weeks, incorporating of sweet pepper extract in to Domiati cheese increased its organoleptic scores. Incorporating of sweet pepper extract decreased the titratable acidity, while incorporating of bifidobacteria increased the acidity of cheese. Neither the incorporation of sweet pepper extract nor the incorporation of bifidobacteria affected significantly the ash and total protein content. Titratable acidity, total volatile fatty acid, soluble nitrogen and organoleptic scores increased throughout pickling period, while total protein content and moisture content decreased. Total bacterial, bifidobacteria and yeasts \& moulds counts increased during the first 4 weeks of pickling period, then decreased up to the end of pickling period. The counts of bifidobacteria in all cheese treatments and even after pickling for 12 weeks were higher than the numbers should be present to achieve the health benefits of bifidobacteria.
\end{abstract}

Key words: Domiati cheese, sweet pepper extract, bifidobacteria, probiotic cheese.

\section{INTRODUCTION}

Domiati cheese is one of the most popular cheeses in Egypt. All efforts today are directed toward the continuous improvement of the product and widen the sales potential of it. The practice of using various flavour additives, which may also be used as preservatives in Domiati cheese manufacture may help to retard alternations caused by growth of microorganisms or enable physical properties, chemical composition, and original nutritional value to remain unaffected, as well as enhancing the sharp, salty taste and favorable flavour appeals to the majority of Egyptian consumers. Mentha sp., Allium sp., Thymus sp., Chaerophyllum sp., Capsicum annuum (sweet pepper) and Capsicum frutescens (hot pepper) are the most favorite flavor used.

Probiotics are "live micro-organisms (bacteria or yeasts), which when ingested or locally applied in sufficient numbers confer one or more specified demonstrated health benefits (FAO/WHO, 2001). Bifidobacteria is a probiotic bacteria show antagonistic effects towards some pathogens, reduce the risk of diarrhea, normalize the bowel movement, enhance immune functions, reduce cholesterol level, reduce the risk of eczema, synthesize several vitamins, protect from cancer and relieve of lactose intolerance symptoms (Martin et al., 2015). Because of these potential roles there has been a growing interest in using bifidobacteria as adjuncts in the dairy industry. The efficacy of added probiotic bacteria depends on dose level. Their viability must be maintained throughout the products shelf-life and they must survive the gut environment. To excerpt their health benefits they have to establish themselves in certain numbers in the gastrointestinal tract. A standard required a minimum of $10^{6}-10^{7}$ colony forming units per gram (cfu $l$ g) of bifidobacteria. (Ahmadi et al., 2014). 
K. M. K. Kamaly, et al.,

Unfortunately, most strains of bifidobacteria do not tolerate the stress environments encountered during manufacture and consumption such as lack of acid tolerance, sensitivity to oxygen, temperature of pickling as well as the gastric juice of stomach (Lankaputhra et al., 1996).

In view of the aforementioned objectives of this study the effect of incorporation of bifidobacteria on cheese quality, investigate the effect of using sweet pepper extract on the survival and viability of bifidobacteria and to monitor the changes of cheese quality during the pickling period.

\section{MATERIALS AND METHODS}

Bacterial strains: Active cultures, Streptococcus thermophilus EMCC 1043, Lactobacillus delbrueckii subsp. bulgaricus EMCC 1102, Bifidobacterium bifidum DSM 20082 and Bifidobacterium infantis ATCC 7469 were obtained from Cairo Mercin, Ain Shams University, Egypt. Bifidobacteria strains were activated by three successive transfers in modified MRS broth medium (Ventling and Mistry, 1993), and incubated at $37^{\circ} \mathrm{C}$ under anaerobic conditions.

Pepper extraction: The pepper was obtained from local market; its washed and their stems cut out then weighed and placed in a blender with an equal amount of isopropanol (1:1 weight/volume); the mix was blended for 1 minute and then shacked for $15 \mathrm{~min}$, afterwards it was filtered through filter paper, and $15 \%$ (w/w) of active charcoal was added to the filtrate, then the mix was gently shaken for $5 \mathrm{~min}$ and filtered again through a Whatman filter paper no.1; the separated solids were discarded and the clear filtrate was evaporated under reduced pressure (46 mbar) at a temperature of $71^{\circ} \mathrm{C}$, and a speed of $28 \mathrm{rpm}$ in order to remove the alcohol. Finally, the extracts were stored at $20^{\circ} \mathrm{C}$ until used (Eleiwa et al. 2014).

Cheese making: Fresh whole buffaloes' milk was obtained from the herd of the Faculty of Agriculture, Menoufia University, Shibin El-kom, Egypt; and standardized to $7.2 \%$ fat. Milk was heated to $72{ }^{\circ} \mathrm{C}$ for $3 \mathrm{~min}$. then cooled rapidly by cold water to $38-40{ }^{\circ} \mathrm{C}$; and then salt $(5.0 \%)$, calcium chloride $(0.02$ $\%)$ and yoghourt starter (1.0\%) were added. The inoculated milk was divided into 6 portions. One was served as control cheese (C); another one was served as control except that $2.0 \%$ of sweet pepper extract was added (T1). Another two treatments were made by inoculation with $2.0 \%$ of Bifidobacterium bifidum one of them was made without adding sweet pepper extract (T2); and the other one was made by adding $2.0 \%$ of sweet pepper extract (T3). The other two treatments were made as described previously except that Bifidobacterium infantis was inoculated instead of Bifidobacterium bifidum (T4 and T5). The rennet was added to all milk batches at the rate of $0.007 \%$. Cheese was made from all batches as described by Fahmi and Sharara (1950). The resultant cheese from each batch was pickled in its salted boiled whey $(7.0 \%$ salt) in plastic bags and stored in refrigerator at $6-8{ }^{\circ} \mathrm{C}$ for 3 months. Samples were taken from each batch every 15 days intervals for microbiological, chemical and sensory evaluation. The whole experiment was triplicated.

Chemical analysis: Titratable acidity, moisture content, $\mathrm{pH}$, ash content, total nitrogen content and water soluble nitrogen content were determined according to A.O.A.C. (2007). The fat content was determined by original Gerber's method as described by Ling (1963); and total volatile fatty acids content was determined according to the method of Kosikowski (1966). 
Microbiological examination: The total bacterial counts were determined using standard plate count agar (Marth, 1978). Modified MRS agar containing solution of antibiotics was used for enumerating bifidobacteria (Ventling and Mistry, 1993). Yeasts and moulds were enumerated on Potato Dextrose Agar (acidified) medium (Difco, 1984).

Organoleptic properties: Cheese samples were evaluated for the appearance, body, texture and flavour by a regular Score panel including the staff members of the Department of Dairy Science and Technology, Menoufia University, Shibin El-Kom, Egypt, according to the scoring sheet of Abdou et al. (1977).

Statistical analysis: 2 ways factorial design was used to analyses all the data and least significant different (LSD) at $p \leq$ 0.05 was followed to make the multiple comparisons among treatments mean (Steel and Torrie, 1980) using Costat program version 6.311 .

\section{RESULTS AND DISCUSSION \\ Chemical analysis:-}

Changes in titratable acidity for control, experimental non flavoured Domiati cheese (T2 and T4) and sweet pepper extract (SPE) flavoured Domiati cheese (T1, T3 and T5) are presented in Table (1). Results showed that titratable acidity of all cheese treatments increased significantly $(p \leq 0.05)$ throughout the pickling period (Table 1,4$)$. It could be concluded that the acidity of flavoured Domiati cheese (T1) was lower than the control; this result may be due to the antimicrobial effect of capsaicin of pepper, while the acidity of the other treatment cheeses (T2, T3, T4 and T5) were higher than the control; because of the incorporation of bifidobacteria which assisted in the formation of the acidity. The acidity of (T3 and T5) were lower than (T2 and T4) respectively; and at the same time it higher than the control; because of the antimicrobial effect of capsaicin.

The $\mathrm{pH}$ values of all treatments are presented in Table (1). The $\mathrm{pH}$ values of all cheese decreased significantly ( $p \leq$ 0.05 ) as pickling period proceeded (Table $1,4)$. These results are in accordance with those of Badawi and Kebary (1996). The average of $\mathrm{pH}$ values of $\mathrm{T} 1$ and $\mathrm{C}$ cheese were generally higher than those of the other (SPE) flavoured Domiati cheese during the period of pickling.

Changes in moisture content for all treatments are shown in Table (1). Moisture content of all cheese treatments gradually decreased significantly ( $p \leq$ 0.05) throughout the pickling period (Table 1, 4). This decrease may be due to curd contraction as a result of the developed acidity during the pickling period. These results are in agreement with those of Kamaly (1978) and Kebary et al. (1996). Cheese containing Bif. bifidum without sweet pepper extract (T2) and with sweet pepper extract (T3) showed declined in moisture content by $19.92 \%$ and $17.22 \%$ from their initial values, respectively. Also, cheese containing Bif. infantis without sweet pepper extract (T4) showed drop in moisture content by $19.79 \%$ from initial value, while cheese containing Bif. infantis with sweet pepper extract (T5) showed drop in moisture content by $16.82 \%$ from initial value. It could be noticed that the moisture content of sweet pepper extract (SPE) flavoured probiotic Domiati cheese containing lower than the control cheese; also, Cheese containing sweet pepper extract and Bifidobacterium bifidum showed lower moisture content than cheese containing sweet pepper extract and Bifidobacterium infantis; because the higher content of acidity of it. Also, it noticed that T1 showed the highest moisture content $(56.74$ at the end of pickling). 
K. M. K. Kamaly, et al.,

Table (1): Changes in the titratable acidity (\%), $\mathrm{pH}$ value, moisture content (\%) and ash content (\%) of sweet pepper extract flavoured probiotic Domiati cheese during the pickling period:-

\begin{tabular}{|c|c|c|c|c|c|c|}
\hline \multirow{2}{*}{ Treatments* } & \multicolumn{6}{|c|}{ Pickling period (weeks) } \\
\hline & 0 & 2 & 4 & 6 & 8 & 12 \\
\hline \multicolumn{7}{|c|}{ Titratable acidity (\%) } \\
\hline C & 0.32 & 0.58 & 0.74 & 0.95 & 1.17 & 1.28 \\
\hline T1 & 0.35 & 0.52 & 0.68 & 0.84 & 1.03 & 1.11 \\
\hline T2 & 0.29 & 0.80 & 1.07 & 1.23 & 1.39 & 1.62 \\
\hline T3 & 0.32 & 0.63 & 0.86 & 1.08 & 1.20 & 1.41 \\
\hline T4 & 0.31 & 0.71 & 0.97 & 1.18 & 1.34 & 1.56 \\
\hline T5 & 0.29 & 0.65 & 0.81 & 0.99 & 1.15 & 1.33 \\
\hline \multicolumn{7}{|c|}{ pH value } \\
\hline C & 6.1 & 5.0 & 4.7 & 4.1 & 3.8 & 3.2 \\
\hline T1 & 6.2 & 5.5 & 5.2 & 4.8 & 4.5 & 3.8 \\
\hline T2 & 6.1 & 4.7 & 4.2 & 3.7 & 3.2 & 2.8 \\
\hline T3 & 6.1 & 4.8 & 4.5 & 4.1 & 3.6 & 3.0 \\
\hline T4 & 6.0 & 4.7 & 4.3 & 3.6 & 3.3 & 2.9 \\
\hline T5 & 6.2 & 4.9 & 4.4 & 4.0 & 3.7 & 3.1 \\
\hline \multicolumn{7}{|c|}{ Moisture content (\%) } \\
\hline C & 63.83 & 61.17 & 59.67 & 57.84 & 55.46 & 54.06 \\
\hline T1 & 64.71 & 62.84 & 60.69 & 59.29 & 58.00 & 56.74 \\
\hline T2 & 63.56 & 60.15 & 58.72 & 55.31 & 52.83 & 50.90 \\
\hline T3 & 63.19 & 62.53 & 59.94 & 56.87 & 54.39 & 52.31 \\
\hline T4 & 64.37 & 61.09 & 58.51 & 56.00 & 53.86 & 51.63 \\
\hline T5 & 63.84 & 61.95 & 59.20 & 56.66 & 54.72 & 53.10 \\
\hline \multicolumn{7}{|c|}{ Ash content (\%) } \\
\hline C & 6.25 & 6.38 & 6.40 & 6.45 & 6.48 & 6.53 \\
\hline T1 & 6.17 & 6.24 & 6.32 & 6.40 & 6.45 & 6.49 \\
\hline T2 & 6.31 & 6.40 & 6.49 & 6.54 & 6.61 & 6.75 \\
\hline T3 & 6.27 & 6.35 & 6.43 & 6.49 & 6.53 & 6.58 \\
\hline T4 & 6.23 & 6.29 & 6.37 & 6.50 & 6.55 & 6.63 \\
\hline T5 & 6.22 & 6.31 & 6.41 & 6.46 & 6.50 & 6.52 \\
\hline
\end{tabular}

${ }^{\star} \mathrm{C}=$ Control cheese. $\mathrm{T} 1$ = Cheese containing $2 \%$ sweet pepper extract.

T2 = Cheese containing $2 \%$ Bifidobacterium bifidum as a probiotic.

$\mathrm{T} 3=$ Cheese containing $2 \%$ sweet pepper extract $+2 \%$ B. bifidum .

$\mathrm{T} 4=$ Cheese containing $2 \%$ Bifidobacterium infantis as a probiotic.

$\mathrm{T} 5=$ Cheese containing $2 \%$ sweet pepper extract $+2 \%$ B. infantis. 
Ash content of all cheese treatments increased slightly. There were no significant $(p>0.05)$ differences among cheese treatments, which means neither the incorporation of sweet pepper extract nor the incorporation of bifidobacteria affected significantly the ash content of resultant cheese treatments (Tables 1, 4). These results are in agreement with those of Badawi and Kebary (1998). This increasing in ash content could be attributed to the loss in moisture content and the reduction of fat content and protein content.

Fat content increased significantly ( $p$ $\leq 0.05$ ) in all cheese treatments during the pickling period (Table 2 and 4). The increase in fat content of cheese during pickling might be due to the expulsion of moisture and consequently the increase in total solids content, and the decrease in solids not fat content due to the partial degradation of protein and their partial loss in whey; these result are in accordance with those of Kamaly (1978) and Fayed (1982). From results, it could be observed that, the cheese (T2, T3, T4 and T5) shows a higher fat percent than control cheese at any stage of pickling period, this might be attributed to the lower moisture content of these treatments than control cheese, in consequence decreasing of the activity of degradation.

Total nitrogen content of all cheese treatments decreased significantly ( $p \leq$ 0.05) throughout the pickling period (Table 2 and 4). This decrease was probably due to protein degradation during pickling period and the formation of water soluble compounds, which lost in the pickling solution. These results are in agreement with those reported of Domiati cheese by Kebary et al. (1996) and Abdou et al. (2003). It was noticed that the control cheese was higher than (T1) in TN but lower than the other treatments, this due to the moisture content and consequently the degradation of protein.

Soluble nitrogen content (SN) is one of proteolysis indices which playing an important role in developing proper body and texture in cheese. SN content of all treatments and control increased significantly $(p \leq 0.05)$ throughout the pickling period (Tables 2 and 4). SN content of all treatments increased markedly during the first 4 weeks of pickling period then increased gradually up to the end of pickling period (12 weeks) as a result of protein degradation. The soluble nitrogen contents of SPE flavoured Domiati cheese was lower than in the control cheese except (T1) was higher than the control at any stage of pickling period.

Total volatile fatty acids contents increased significantly $(p \leq 0.05)$ in all cheese treatments as pickling period proceeded (Tables 2 and 4); it increased markedly during the first 4 weeks of pickling then increased gradually up to the end of pickling period. These results are in agreement with those reported for Domiati cheese by Kamaly (1978) and Abd El-Gawad and Hassan (2000). The total volatile fatty acids content was increased as a result of degradation of fat on cheese, and noticed that the treatment which containing the highest moisture content containing the highest TVFA content (T1); while, (T2) was the lowest content of TVFA where the lower content of moisture.

\section{Microbiological examination:-}

The bacterial counts increased during the first 4 weeks then markedly decreased until the end of pickling period (12 weeks), these results are in accordance with those of Fayed (1982). The bacterial counts of all treatments and control decreased significantly $(p \leq 0.05)$ throughout the pickling period (Table 3 and 4). The sweet pepper extract (SPE) 
K. M. K. Kamaly, et al.,

flavoured Domiati cheese was lower in total bacteria counts than control. These results are in agreement with those reported for Domiati cheese by Kamaly
(1978)); this may be due to the antibacterial activity for the sweet pepper extract.

Table (2): Changes in the fat content (\%), total nitrogen (\%), soluble nitrogen (\%) and total volatile fatty acid ( $\mathrm{ml} 0.1 \mathrm{~N} \mathrm{NaOH} / 100 \mathrm{~g}$ cheese) of sweet pepper extract flavoured probiotic Domiati cheese during the pickling period:-

\begin{tabular}{|c|c|c|c|c|c|c|}
\hline \multirow{2}{*}{ Treatments* } & \multicolumn{6}{|c|}{ Pickling period (weeks) } \\
\hline & 0 & 2 & 4 & 6 & 8 & 12 \\
\hline \multicolumn{7}{|c|}{ Fat content (\%) } \\
\hline C & 11.16 & 13.10 & 15.80 & 17.62 & 20.65 & 22.20 \\
\hline T1 & 11.52 & 12.37 & 14.91 & 16.84 & 18.80 & 20.69 \\
\hline T2 & 12.97 & 15.35 & 18.86 & 22.14 & 25.26 & 27.75 \\
\hline T3 & 10.64 & 13.83 & 15.45 & 19.57 & 22.65 & 25.13 \\
\hline T4 & 12.38 & 14.72 & 17.70 & 20.00 & 24.87 & 26.71 \\
\hline T5 & 11.86 & 13.75 & 16.89 & 18.76 & 21.42 & 23.66 \\
\hline \multicolumn{7}{|c|}{ Total nitrogen (\%) } \\
\hline C & 2.20 & 2.08 & 1.96 & 1.90 & 1.85 & 1.81 \\
\hline T1 & 2.24 & 2.11 & 1.97 & 1.89 & 1.82 & 1.79 \\
\hline T2 & 2.28 & 2.17 & 2.09 & 2.02 & 1.97 & 1.91 \\
\hline T3 & 2.19 & 2.09 & 1.98 & 1.92 & 1.86 & 1.84 \\
\hline T4 & 2.26 & 2.14 & 2.03 & 1.96 & 1.91 & 1.87 \\
\hline T5 & 2.23 & 2.10 & 1.98 & 1.90 & 1.86 & 1.83 \\
\hline \multicolumn{7}{|c|}{ Soluble nitrogen (\%) } \\
\hline C & 0.19 & 0.41 & 0.66 & 0.78 & 0.86 & 0.97 \\
\hline T1 & 0.18 & 0.40 & 0.70 & 0.84 & 0.90 & 0.99 \\
\hline T2 & 0.21 & 0.36 & 0.57 & 0.69 & 0.79 & 0.84 \\
\hline T3 & 0.19 & 0.38 & 0.60 & 0.71 & 0.80 & 0.90 \\
\hline T4 & 0.15 & 0.40 & 0.65 & 0.73 & 0.80 & 0.86 \\
\hline T5 & 0.16 & 0.39 & 0.62 & 0.79 & 0.88 & 0.95 \\
\hline \multicolumn{7}{|c|}{ Total volatile fatty acid (ml $0.1 \mathrm{~N} \mathrm{NaOH} / 100 \mathrm{~g}$ cheese) } \\
\hline $\mathbf{C}$ & 7.30 & 14.70 & 21.90 & 26.50 & 30.10 & 33.20 \\
\hline T1 & 7.20 & 13.90 & 22.20 & 26.60 & 31.30 & 35.00 \\
\hline T2 & 7.00 & 12.10 & 17.30 & 22.80 & 26.50 & 28.60 \\
\hline T3 & 7.10 & 13.20 & 19.60 & 25.30 & 28.20 & 30.10 \\
\hline T4 & 7.40 & 13.60 & 19.10 & 23.30 & 27.90 & 29.50 \\
\hline T5 & 7.20 & 15.15 & 20.40 & 25.90 & 29.10 & 32.10 \\
\hline
\end{tabular}

*See Table (1). 
Table (3): Changes in the total bacterial counts, bifidobacteria counts, yeasts and moulds count ( $\log _{10}$ cfu I g cheese) and organoleptic properties of sweet pepper extract flavoured probiotic Domiati cheese during the pickling period:-

\begin{tabular}{|c|c|c|c|c|c|c|}
\hline \multirow{2}{*}{ Treatments* } & \multicolumn{6}{|c|}{ Pickling period (weeks) } \\
\hline & 0 & 2 & 4 & 6 & 8 & 12 \\
\hline \multicolumn{7}{|c|}{ Total bacterial counts $\left(\log _{10} \mathrm{cfu} / \mathrm{g}\right.$ cheese) } \\
\hline C & 7.64 & 8.08 & 8.11 & 7.89 & 7.35 & 6.88 \\
\hline T1 & 7.70 & 7.82 & 8.00 & 7.72 & 7.19 & 6.79 \\
\hline T2 & 7.73 & 8.00 & 8.19 & 7.80 & 7.29 & 6.90 \\
\hline T3 & 7.77 & 7.93 & 7.98 & 7.70 & 7.20 & 6.76 \\
\hline T4 & 7.73 & 8.03 & 8.13 & 7.85 & 7.30 & 6.93 \\
\hline T5 & 7.68 & 7.98 & 8.04 & 7.74 & 7.16 & 6.82 \\
\hline \multicolumn{7}{|c|}{ Bifidobacterial counts $\left(\log _{10} \mathrm{cfu} / \mathrm{g}\right.$ cheese) } \\
\hline C & -- & -- & -- & -- & -- & -- \\
\hline T1 & -- & -- & -- & -- & -- & -- \\
\hline T2 & 7.44 & 7.58 & 7.67 & 7.32 & 7.13 & 6.96 \\
\hline T3 & 7.44 & 7.56 & 7.64 & 7.26 & 7.06 & 6.81 \\
\hline T4 & 7.44 & 7.59 & 7.70 & 7.35 & 7.16 & 6.92 \\
\hline T5 & 7.44 & 7.55 & 7.61 & 7.21 & 7.08 & 6.65 \\
\hline \multicolumn{7}{|c|}{ Yeasts and Moulds count ( $\log _{10} \mathrm{cfu} / \mathrm{g}$ cheese) } \\
\hline C & 4.33 & 4.09 & 3.88 & 3.40 & 3.07 & 2.64 \\
\hline T1 & 4.39 & 4.00 & 3.64 & 3.22 & 2.57 & -- \\
\hline T2 & 4.32 & 4.06 & 3.92 & 3.37 & 2.99 & 2.61 \\
\hline T3 & 4.33 & 4.03 & 3.61 & 3.29 & 2.87 & 2.10 \\
\hline T4 & 4.38 & 4.11 & 3.85 & 3.42 & 3.02 & 2.52 \\
\hline T5 & 4.35 & 4.11 & 3.55 & 3.03 & 2.17 & -- \\
\hline \multicolumn{7}{|c|}{ Organoleptic properties } \\
\hline C & 89 & 91 & 90 & 91 & 92 & 94 \\
\hline T1 & 89 & 90 & 92 & 94 & 93 & 94 \\
\hline T2 & 88 & 91 & 91 & 92 & 93 & 95 \\
\hline T3 & 90 & 92 & 93 & 92 & 95 & 96 \\
\hline T4 & 89 & 91 & 91 & 91 & 92 & 93 \\
\hline T5 & 89 & 91 & 91 & 91 & 93 & 95 \\
\hline
\end{tabular}

*See Table (1). 
K. M. K. Kamaly, et al.,

Table (4): Statistical analysis of sweet pepper extract flavoured probiotic Domiati cheese properties during the pickling period:-

\begin{tabular}{|c|c|c|c|c|c|c|c|c|c|c|c|c|c|c|}
\hline \multirow{3}{*}{$\begin{array}{l}\text { Cheese } \\
\text { properties }\end{array}$} & \multicolumn{7}{|c|}{ Effect of treatments } & \multicolumn{7}{|c|}{ Effect of pickling period (weeks) } \\
\hline & \multicolumn{7}{|c|}{ Multiple comparisons" } & \multicolumn{7}{|c|}{ Multiple comparisons" } \\
\hline & $\begin{array}{c}\text { Mean } \\
\text { Squares }\end{array}$ & $c^{\bullet}$ & T1 & T2 & T3 & T4 & T5 & $\begin{array}{c}\text { Mean } \\
\text { squares }\end{array}$ & 0 & 2 & 4 & 6 & 8 & 12 \\
\hline $\begin{array}{l}\text { Titratable acidity } \\
\text { (\%) }\end{array}$ & 0.882 & C & a & a & b & a & b & $5.569^{*}$ & c & bc & bc & b & b & a \\
\hline $\begin{array}{l}\text { Moisture content } \\
\text { (\%) }\end{array}$ & $34.600 *$ & Ab & a & c & c & c & bc & $312.710^{*}$ & a & b & b & c & c & d \\
\hline $\mathrm{pH}$ values & $1.897^{*}$ & B & a & c & b & c & b & $19.748^{*}$ & a & b & c & d & e & f \\
\hline Ash content (\%) & 0.053 & A & a & a & a & a & a & 0.277 & c & cb & abc & abc & $a b$ & a \\
\hline Fat content (\%) & $51.490^{*}$ & D & e & a & c & b & c & $416.570^{*}$ & f & e & d & c & b & a \\
\hline TVFA & 34.741 & Ab & a & d & c & c & b & $1548.441^{*}$ & f & e & d & c & b & a \\
\hline Total nitrogen (\%) & 0.034 & A & a & a & a & a & a & $0.386^{*}$ & a & ab & bc & c & c & c \\
\hline $\begin{array}{l}\text { Soluble nitrogen } \\
\text { (\%) }\end{array}$ & $0.021^{*}$ & B & a & d & c & c & b & $1.447^{*}$ & $\mathbf{f}$ & $\mathbf{e}$ & d & c & b & a \\
\hline $\begin{array}{l}\text { Total bacterial } \\
\text { counts }\end{array}$ & 0.071 & A & a & a & a & a & a & $3.944^{*}$ & c & $a b$ & a & bc & d & e \\
\hline $\begin{array}{l}\text { Bifidobacteria } \\
\text { counts }\end{array}$ & $256.899 *$ & B & b & $\mathbf{a}$ & $\mathbf{a}$ & $\mathbf{a}$ & $\mathbf{a}$ & $0.753^{*}$ & $a b$ & $\mathbf{a}$ & $\mathbf{a}$ & bc & c & d \\
\hline $\begin{array}{l}\text { Yeasts\&Moulds } \\
\text { counts }\end{array}$ & $1.686^{*}$ & A & a & a & a & a & a & $17.843^{*}$ & a & $a b$ & b & bc & d & e \\
\hline Total score & 10.360 & A & b & a & B & a & b & 31.648* & c & bc & $\mathbf{a b}$ & ab & a & a \\
\hline
\end{tabular}

- See Table (1).

* Significant at 0.05 level $(p \leq 0.05)$.

- For each effect the different letters in the same row means the multiple comparisons are different from each other, letter (a) is the highest mean followed by (b), (c), ... etc.

The bifidobacteria counts increased during the first 4 weeks then decreased till the end of pickling period, although their numbers did not decrease under the theoretical value $\left(10^{6} \mathrm{cfu} / \mathrm{g}\right)$. These results are in with those of El-Wakeel (2002). The bifidobacteria counts of all cheese treatments and control decreased significantly $(p \leq 0.05)$ during the pickling period (Tables 3 and 4). The bifidobacteria counts of sweet pepper extract (SPE) flavoured Domiati cheese T3 and T5 was lower than T2 and T4; these may be attributed to the 
antimicrobial activity of the sweet pepper extract.

The moulds and yeasts counts slightly increased during the first 4 weeks then decreased until the end of pickling period (12 weeks). The moulds and yeasts count of all treatments and control decreased significantly ( $p \leq 0.05$ ) throughout the pickling period (Table 3 and 4). The counts of moulds and yeasts of sweet pepper extract (SPE) flavoured Domiati cheese was lower than the control at any stage pickling period, these results are in agreement with those of Kamaly (1978), and this may be due to the capsaicin content which inhibits the growth of moulds and yeasts.

\section{Organoleptic properties:-}

The organoleptic properties of all cheese treatments cheese was increased significantly ( $p \leq 0.05$ ) as the pickling period proceeded (Tables 3 and 4); this increase might be due to the improvement in flavour, body and texture as a result of protein degradation and fat lipolysis during the pickling period. The results are in accordance with those of Kebary et al. (1996). The highest total score was found in T1, T3 and T5. The fresh cheese samples are characterized by a soft firm body with a clean smell and salty flavour; the pickling cheese on the other hand, has a sharp flavour with a spreadable body and smooth compact texture. From results, it was clear that (SPE) flavoured Domiati cheese, showed high score during the pickling period. This can be attributed to (SPE) which gives cheese the desirable flavour particularly for cheese aroma. Obtained results are in agreement with those of Kamaly (1978) and Fayed (1982).

\section{REFERENCES}

Abd El-Gawad, M. A. M. and A. M. Hassan (2000). Manufacture of low fat soft white cheese by using fat replacers. Arab-Univ. J. Agric. Sci., 8: 253.

Abdou, S. M., L. B. Abd-El-Hamid, A. H. M. Dawood, A. M. Youssef and G. A. Mahran (1977). Studies on Cephalotyre "Ras" cheese coating. II. Effect on pickling period. Egypt $J$. Dairy Sci., 5:191.

Abdou, S. M., M. E. Shenana, S. G. Osman and A. M. Sadek (2003). Production of low-fat Halloumi cheese. Egypt J. Dairy Sci., 31: 101.

Ahmadi, A., E. Milani, A. Madadlou, S.A. Mortazavi, R.R. Mokarram and D. Salarbashi (2014). Synbiotic yoghurtice-cream produced via incorporation of microencapsulated Lactobacillus acidophilus (La-5) and fructooligosaccharide. J. Food Sci. and Tech., 51: 1568.

A.O.A.C. (2007). Official Method of the Association of Analytical Chemists. $17^{\text {th }}$ Ed. Published by the Association of Official Analytical Chemists, Po. Box 540. Benjamin Franklin Station, Washington, D.C. 20044.

Badawi, R. M. and K. M. K. Kebary (1996). Accelerated pickling period of Domiati cheese by partial lyzed lactococci. Menofiya J. Agric. Res., 21: 63.

Badawi, R. M. and K. M. K. Kebary (1998). Influence of fat replacers on the quality of low fat Tallaga cheese. Proc. of the 7th Egypt Conf. for Dairy Sci. and Tech.; Cairo, Egypt, 7 - 9 Nov., 347.

Difco (1984). Manual and dehydrated culture media and reagents for microbiology $10^{\text {th }}$ ed. Difco Laboratories, Detriot, Michigan.

Eleiwa, N. Z. H. and A. H. El-Gohary (2014). Studies the effect of temperature, pH and capsicum annuum extract on the viability of listeria monocytogenes in Kareish cheese. Vedic Res. Inter. phytomedicine, 2: 22.

El-Wakeel, O. A. M. (2002). Nutr.al, technological and microbiogical 
studies on soft cheeses by using of bifidobacteria as a probiotic culture. M.Sc. Thesis, Nutr. \& Food Sci. Department, Faculty of Economics, ElMonoufia Univ., Egypt.

Fahmi, A. H. and H. A. Sharara (1950). Studies on Egyptian "Domiati" cheese. J. Dairy Res.; 17: 312.

FAO/WHO (2001). Evaluation of health and nutritional properties of probiotics in food including powder milk with live lactic acid bacteria. Report of joint FAO/WHO expert consultation, Cordoba, Argentina.

Fayed, E. O. (1982). Studies on the use of some natural flavour agents on the pickling period of pickled Domiati cheese. PH.D. Thesis, Faculty of Agric.; Ain-Shams Univ.; Egypt.

Kamaly, K. M. (1978). Studies on the effect of some plant flavours additives on Domiati cheese. M.Sc. Thesis, Food Sciense Department, Faculty of Agric., El-Monoufia Univ.; Egypt.

Kebary, K. M., K. M. Kamaly, A. N. Zedan and A. Zaghlol (1996). Accelerated pickling period of Domiati cheese by accelase and lipozymes. Egpyt $J$. Dairy Sci., 24: 75.

Kosikowski, F. V. (1966). Cheese and Fermented Milk Foods. Edward
Brothers, Inc., Ann. Arbor., Mich., USA.

Lankaputhra, W.E.V., N.P. Shah and M.L. Britz (1996). Survival of bifidobacteria during refrigerated pickling in the presence of acid and hydrogen peroxide. Milchwissenschaft. 51: 65 .

Ling, E.R. (1963). A Text Book of dairy Chem., Vol. 2 Practical $3^{\text {rd }}$ ed. Chapman \& Hall, Ltd., London.

Marth, E.H. (1978). Standard methods for the examination of dairy products, $14^{\text {th }}$ ed. Am. Publ. Health Assoc. Washington, DC.

Martin, M. J., F. Lara-Villoslada, M. A. Ruis and M.E. Morales (2015). Microencapsulation of bacteria: A review of different technologies and their impact on the probiotic effects. Innovative Food Sci. and Emerging Tech.; 27: 15.

Steel, R. G. D. and J. H. Torrie (1980). Principles and Procedures of Statistics. A biometrical approach. $2^{\text {nd }}$ Ed. McGraw-Hill Book Co., New York.

Ventling, B. L. and V. V. Mistry (1993). Growth characteristics of bifidobacteria in ultrafiltered milk. J. Dairy Sci., 76: 962. 
خواص الجبن الدمياطى الاعم للحيوية المطعم بالقلقل الأخضر

كمال محمد كمالى ، خميس محمد كعبارى ، رجب محمد بدوى ، أحمد محمد عبد العظيم جعفر قسم علوم وتكنولوجيا الألبان - كلية الززاعة - جامعة المنوفية كلية

الملخص العربى

تم تصنيع 1 معاملات من الجبن الامياطى للاراسة تأثير إضافة مسخلص الفلفل الحلو ويكتريا الـ bifidobacteria

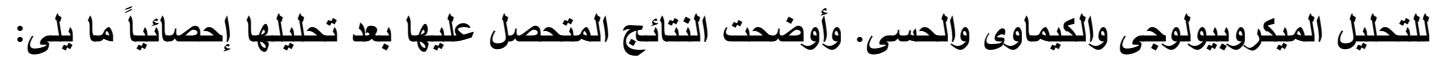

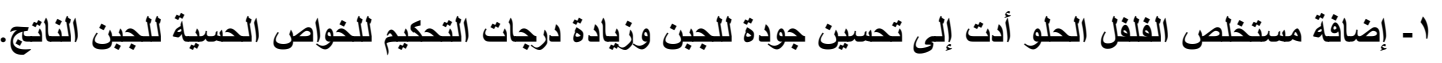

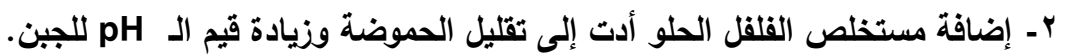

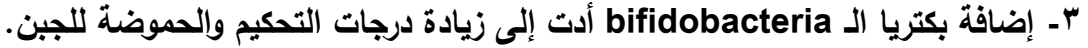

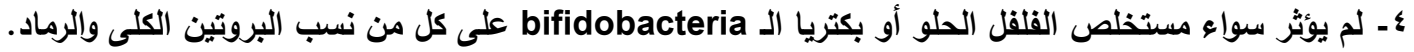

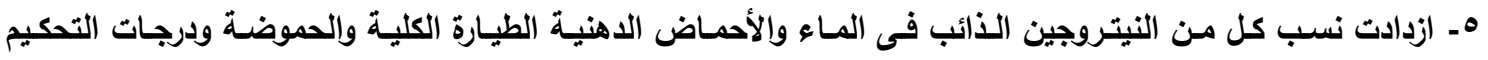

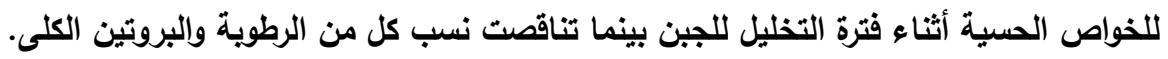

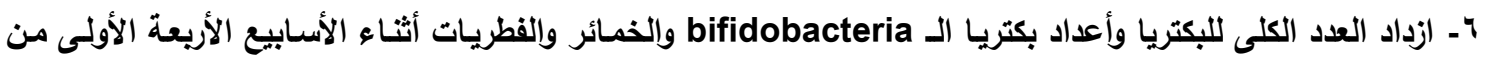

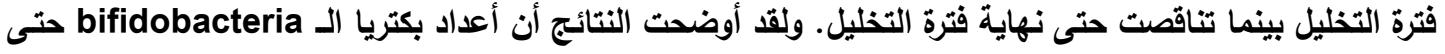

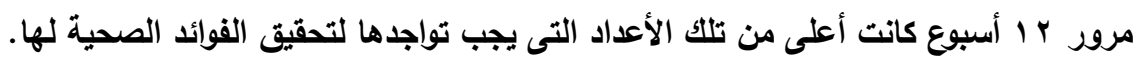


K. M. K. Kamaly, et al., 